\title{
„Už mě to tam nebavilo“ - absentérství žáků středních odborných škol v kontextu odpoutávání od školy
}

\author{
Klára Šlapalová, Petr Hlad'o \\ Masarykova univerzita, Filozofická fakulta
}

\begin{abstract}
Abstrakt: Vysoké absence žáků představují závažný problém českého středního odborného školství a celkové počty zameškaných hodin mají v průběhu let vzestupnou tendenci. Cílem předkládané studie je proto odhalit a popsat, jak žáci středních odborných škol a středních odborných učilišt' vnímají své absentérství. Na problematiku školního absentérství je nahliženo optikou žáků, kteří reflektují své zkušenosti s úmyslným zameškáváním školní výuky během odpoutávání od školy. Kvalitativní data od jedenácti respondentů byla získána prostřednictvím ohniskových skupin a individuálních hloubkových rozhovorů. Z výsledků je patrné, že absentérství je úzce spojeno s postupným odpoutáváním od školy, představuje rizikový faktor školního neúspěchu a může vyústit v odchod ze školy. Žáci absentéři se odmítají účastnit školního vyučování zpravidla kvưli svému nezájmu o výuku, nízké atraktivitě učiva či pocit’ované nudě ve škole. Klíčovou roli v tomto procesu hraji spolužáci a vrstevníci, kteří se ve své nepravidelné školní docházce navzájem ovlivňují a společně si alternativní program místo školního vyučování volí a plánují. Analýza dat navíc odhalila nejednotnost $v$ pravidlech škol týkajících se školní docházky, v kontrole jejich dodržování a v prevenci před projevy záškoláctví. Kvůli nedostatečné intervenci ze strany školy jsou kritické důsledky absentérství odhaleny až s delším časovým odstupem, kdy lze jen stěží zabránit závažným negativním dopadům na vzdělávací dráhu žáka.
\end{abstract}

Klíčová slova: školní absentérství, záškoláctví, školní docházka, žák střední školy

\section{"I Got Tired of It" - Absenteeism Among Vocational Upper-Secondary School Students in the Context of School Disengagement}

Abstract: Students' high absenteeism represents a serious issue in Czech vocational education at the upper-secondary school level, and the overall number of missed lessons keeps rising. The aim of the presented study is to reveal and describe how vocational high school and training high school students perceive their absenteeism. Therefore, school absenteeism is viewed from the students' perspective while reflecting their own experiences with skipping school intentionally while experiencing school disengagement. The qualitative data obtained from eleven respondents were collected through focus groups and individual in-depth interviews. It is evident from the results that absenteeism is closely connected with gradual school disengagement, represents a risk factor of school failure and can result in school drop-out. Students-absentees refuse to attend classes at school usually due to their lack of interest in the lessons, low attractiveness of the lessons' content or experiencing boredom at school. Classmates and peers play a key role in the whole process as they influence each other in the means of irregular school attendance, and together they also choose and plan the alternative program substituting school attendance. Furthermore, the data analysis revealed inconsistency related to the schools' rules on school attendance, monitoring students' compliance with these rules and prevention of truancy. Due to the lack of intervention 
82 by the school, the critical consequences of absenteeism are revealed after a long period of time when it is difficult to avoid negative impacts on the student's educational path.

Keywords: school absenteeism, truancy, school attendance, high school student

Pravidelná školní docházka zásadně přispívá ke školní úspěšnosti žáků a ovlivňuje jejich budoucnost (Gottfried, 2014; Önder, 2017). Př́tomnost ve škole zvyšuje šance žáků na rozvoj jejich akademických, odborných, jazykových a sociálních dovedností (Kearney \& Graczyk, 2014; Şahin, Arseven, \& Kılıç, 2016), a proto není-li žák ve vyučování často přítomen, nemǔže príležitostí k rozvoji svých dovedností využít a může být oproti svým spolužákům znevýhodněn (Thornton, Darmody, \& McCoy, 2013). Zatímco se občasné zameškání školní výuky nejeví jako problematické, u časté absence výzkumy ukazují opak - at' už jsou důvody pro zameškání výuky jakékoliv, absentérství má prokazatelně negativní vliv na výsledky ve vzdělávání, zvyšuje pravděpodobnost předčasného ukončení školní docházky a je jedním z rizikových faktorů deviantního chování (Česká školní inspekce, 2016, 2017; Hunt et al., 2002; Kearney, 2008; Thornton et al., 2013; Trhlíková, 2012). Z tohoto důvodu se absentérství jeví jako klíčový koncept při snaze pochopit úspěch a neúspěch ve vzdělávání (Jonasson, 2011).

Vysoká absence žáků představuje jeden z hlavních problémů českého středního školství (Česká školní inspekce, 2017). Celkový počet zameškaných hodin na jednoho žáka činil za školní rok 2017/2018 v prủměru 132 vyučovacích hodin, z toho 5 neomluvených. Jako hlavní př́činy neomluvených hodin uvádějí ředitelé škol neschopnost žáků přizpůsobit se školnímu režimu, vliv rodinného prostředí, vliv mimoškolního a volnočasového prostředí a obavy ze školního neúspěchu. Záškoláctví rovněž představuje nejčastější rizikové chování, a to na 65 \% středních škol v České republice (Česká školní inspekce, 2019).

Cílem této studie je prozkoumat fenomén absentérství skrze perspektivu žáků středních škol a odhalit vnímání jejich vlastních zkušeností s absentérstvím. Centrem pozornosti předkládané studie jsou absentéři, kteří meškali výuku na základě svého vlastního rozhodnutí, vyhýbali se školní docházce úmyslně a místo ní se věnovali jiným činnostem. Komplexní povaha problematiky absentérství vyžaduje důkladné vymezení základních pojmů, které je rovněž součástí studie.

\section{1 Školní absentérství}

Školní absentérství (school absenteeism; dále jen absentérství) označuje nepřítomnost žáka ve výuce $v$ základní či střední škole a v dalších činnostech, které jsou školou předepsány jako povinné. Zatímco někteří autoři považují za absentérství pouze nepř́tomnost, která není řádně omluvena (např. Průcha, Walterová, \& Mareš, 2009), podle jiných autorů, včetně autorů předložené studie, absentérství označuje omluvenou i neomluvenou neprítomnost žáka (Balfanz \& Byrnes, 2012; Kearney, 
2008; Thornton et al., 2013; aj.). Definice absentérství se shodují v dalších typických rysech, kterými jsou častá nepř́tomnost žáka a její negativní dopady v krátkoi dlouhodobém horizontu (kupř. Önder, 2017).

Absentérství lze považovat za určitý zastřešující pojem, který zahrnuje různé podoby zameškávání výuky. Má-li žák zameškáno $10 \%$ a více běžné výuky, užívá se pro jeho jednání termín chronické absentérství (chronic absenteeism, persistent absenteeism), které se zpravidla odvíjí od celkového počtu zameškaných dnů bez ohledu na důvod absence (Balfanz \& Byrnes, 2012). Jedná se jak o zameškané hodiny $\vee$ rámci za sebou jdoucích školních dní, tak i o průběžné absence napříc školním rokem (Gottfried, 2014). V případě, že žák není ve škole přítomen a zároveň nemá zameškané hodiny omluvené, se jeho chování označuje jako záškoláctví (truancy) a děje se většinou bez vědomí rodičů jedince (Fremont, 2003). Záškoláctví představuje zvláštní př́pad absentérství a jde ruku $v$ ruce s porušováním pravidel, s nezájmem žáka o povinnosti spjaté se vzděláváním a s problémy v oblasti chování a prospěchu (Balfanz \& Byrnes, 2012). Takový žák je tedy absentérem a současně i záškolákem, zatímco kupř. žák, kterému absence omlouvají rodiče a jenž zůstává z rodinných důvodů místo výuky doma, je považován pouze za absentéra, nikoli za záškoláka. Jednání typické pro záškoláctví se liší od další formy absentérství, kterou je odmítavý postoj ke škole (school refusal behaviour). Pro něj jsou typické pocity úzkosti a strachu pramenící ze školní docházky (Kearney, 2008). Jedná se o žáky, kteří nechodí do školy kvưli šikaně, obtěžování, nebezpečným podmínkám školy či studu (Balfanz \& Byrnes, 2012). Na rozdíl od záškoláctví rodiče žáka o jeho absencích zpravidla vědí, jelikož často zůstává místo výuky v domácím prostředí, kde se cítí $\checkmark$ bezpečí, je ochotný plnit si své školní povinnosti a nevyznačuje se antisociálním chováním (Fremont, 2003).

Zahraniční odborná literatura je poměrně bohatá na témata absentérství, omluvených i neomluvených zameškaných hodin, pozdních př́chodů či záškoláctví. Výzkumy se $v$ této oblasti zaměřují jak na žáky primárního a nižšího sekundárního stupně (např. Thornton et al., 2013), tak i na žáky vy̌šího sekundárního (mj. Ishak \& Fin, 2013) nebo terciárního stupně vzdělávání (kupř. Barlow \& Fleischer, 2011; Gump, 2006). V některých výzkumech jsou sesbíraná data analyzována dohromady bez rozlišování stupně vzdělávání či věku žáků (Şahin et al., 2016; Stempel et al., 2017; aj.). Ačkoli se absentérstvím zpravidla myslí nepřitomnost žáka ve škole, zahraniční autoři pracují rovněž s pojmem absence in class, tedy s absentérstvím, při němž žák plní povinnou školní docházku, ale neplní své školní povinnosti. Tomuto konceptu se věnuje mj. Jonassonová (2011) a odlišuje jej od běžné formy absentérství (absence from class), protože i přesto, že je žák ve škole př́tomen, volí jiné činnosti, které nesouvisejí s výukou, např. spaní nebo posílání textových zpráv.

Při snaze o komparaci výsledků výzkumů v oblasti školní docházky a absentérství mezi různými zeměmi vyplývají na povrch některé skutečnosti, které činí srovnávání obtížné a v některých př́padech téměř nemožné. Jedná se především o nejednotnou terminologii spolu s odlišnými pravidly pro školní docházku platnými pro jednotlivé země. Problematická je $v$ této oblasti neexistence obecné definice absentérství a zá- 
84 školáctví a značné rozdíly při stanovení minimálního počtu zameškaných hodin, jenž indikuje absentérství a záškoláctví (srov. Birioukov, 2016; Sutphen, Ford, \& Flaherty, 2010). Navíc zatímco v rámci Evropy se běžně uživá termín záškoláctví, v Severní Americe je tento koncept označován spí̌̌e jako neomluvené absence (unexcused absences) a je považován za synonymní ke zmíněnému záškoláctví (Birioukov, 2016). Zaměříme-li se pouze na př́činy zameškávání výuky, je zde patrná dvojí tendence autorů. V centru pozornosti první skupiny výzkumů stojí absence vznikající z důvodu nemoci či zranění, zatímco druhá skupina se zpravidla soustřed'uje na neomluvené absence spojené s různými sociálními překážkami, psychickými problémy a dalšími negativními jevy (Kearney, 2008). Ačkoli prríčiny vedoucí k absentérství spolu často navzájem úzce souvisejí a nejsou zcela jasně dělitelné, lze rozlišit př́činy spojené se školou na straně jedné a přičiny, které spiše souvisejí s životními podmínkami jedince na straně druhé (Birioukov, 2016). Podrobnější dělení přičin do čtyř kategorií nabízí důvody pro absentérství z oblastí žák, rodina, škola a komunita (Sutphen et al., 2010), př́padně z pěti kategorií prričin, kterými jsou dle Şahinové et al. (2016) žák, rodina, škola, učitelé a prostředí (do něj patří např. špatné počasí nebo problémy s dopravou).

Na rozdíl od situace $v$ zahraniči česká odborná literatura oblast absentérství téměř opomíjí. Pozornost jí je $v$ určité míre věnována $v$ publikacích $s$ praktickým přesahem, jež jsou určeny pro pedagogické pracovníky (např. Petrák, 2012; Svobodová, 2012, 2015). Hlavní sondu do této problematiky u nás představují každoroční výroční zprávy České školní inspekce $(2016,2017,2018,2019)$ se statistickými údaji týkajícími se záškoláctví a dalších projevů rizikového chování. Možnosti řešení této problematiky optikou školních psychologů nabízí ve své studii Hlaváčová (2015). Tématem absentérství v kontextu předčasných odchodů ze vzdělávání na středních školách se zabývala Trhlíková (2012). Autorka, která prováděla expertní hloubkové rozhovory s pracovníky škol, zmiňuje jako hlavní důvody zameškávání výuky nezájem o školu nebo o obor, ekonomickou aktivitu (brigády) a především pak rodinné zázemí, v němž chybí běžné vzory plnění povinností, kontrola docházky, nebo je naopak patrná snaha rodičủ absence svých dětí krýt a omlouvat.

Z výše uvedeného je zřejmé, že problematika absentérství je komplexního rázu, a proto vyžaduje pečlivé zacházení s termíny a jejich významy. Zmíněná komplexnost zpưsobuje, že celá oblast absentérství a školní docházky zahrnuje další koncepty, jež lze nejlépe odhalit a uchopit prostřednictvím perspektivy samotných aktérů, tedy jedinců majících s tímto fenoménem osobní zkušenost.

\section{Metoda}

Cílem předložené studie je zjistit a porozumět tomu, jak žáci středních odborných škol a středních odborných učilišt' vnímají své absentérství v kontextu vlastního odpoutávání od školy. $V$ centru zájmu se tedy nachází absentérství, na něž je nahliženo optikou aktérů reflektujících své vlastní zkušenosti se zameškáváním školní docházky, které u nich vedlo k reaktivnímu non-normativnímu přestupu na jinou 
střední školu. Vzhledem $\mathrm{k}$ tomu, že kvantitativní př́stup může jen stěží zaznamenat všechny okolnosti, které mohou mít vliv na žákovu nepř́tomnost ve škole (Birioukov, 2016), pro bližší porozumění problematice absentérství byla zvolena kvalitativní výzkumná strategie.

\subsection{Kontext výzkumu}

Potřebu hlubšího prozkoumání fenoménu absentérství u českých žáků naznačuje mj. skutečnost, že se tato tematika vynořila spontánně při realizaci šířeji koncipovaného výzkumného šetření s názvem Důvody žáků pro opakovaný přestup na jinou střední školu zaměřeného na problematiku meziškolní mobility žáků v rámci vyššího sekundárního stupně vzdělávání, z něhož předložená studie vychází. Výzkum byl iniciován odborem školství Jihomoravského kraje (JmK) a byl uskutečněn pod jeho záštitou. Empirické šetření probíhalo od září 2017 do března 2018 a bylo realizováno Ústavem pedagogických věd Filozofické fakulty Masarykovy univerzity. Jak bylo uvedeno výše, absentérství a zkušenosti respondentů se školní docházkou jako takovou nepatřily mezi stěžejní oblasti zájmu zmíněného výzkumu, avšak již na počátku sběru dat se ukázaly jako klíčová témata pro žáky, a to $\mathrm{v}$ souvislosti s procesem odpoutávání od školy, potažmo s reorientací v započaté vzdělávací dráze jedince. Přestože meziškolní mobilita žáků není předmětem předkládaného textu, je důležité zmínit její kličcovou roli, kterou sehrála při výběru respondentů.

\subsection{Výzkumný vzorek}

V souladu s metodologií kvalitativního výzkumu probíhal výběr vzorku záměrně s ohledem na cíl výzkumného šetření. Při vzorkování byly v prvním kroku, na základě údajů o meziškolní mobilitě žáků v Jihomoravském kraji, vybrány odborem školství JmK čtyři střední školy, které ve školním roce 2016/2017 vykazovaly vysokou míru meziškolní mobility žáků. Jednalo se o tři střední odborné školy a jedno střední odborné učiliště. $V$ druhém kroku byl $v$ každé škole požádán jeden pedagogický pracovník (šlo o jednoho zástupce ředitele a tři učitele, z nichž jeden současně pưsobí jako výchovný poradce), jehož úkolem bylo $v$ dané vzdělávací instituci vytipovat žáky, kteří splňovali vymezená kritéria. Volba jednotlivých žáků byla tedy zcela v kompetenci oslovených pedagogických pracovníků, kteří disponují informacemi o vzdělávací dráze jednotlivých studentů. Pedagogičtí pracovníci vybrané žáky oslovili, poskytli jim základní informace o účelu výzkumu a rovněž zajistili informované souhlasy. Oslovení žáci splňovali podmínku alespoň jedné podstoupené změny školy v průběhu vyššího sekundárního vzdělávání, a to z jiného důvodu než stěhování, či změna bydliště.

Pro účely této studie bylo nutné z žáků, kteři se zúčastnili zastřešujícího výzkumu, zkonstruovat dílčí vzorek. Zvoleni byli pouze žáci, kteří zmiňovali své zkušenosti s absentérstvím na předchozí střední škole, již studovali před přestupem. Z celkového počtu 31 respondentů, kteří tvořili výzkumný vzorek výše zmíněného výzkumu 
86 zaměřeného na meziškolní mobilitu, bylo tedy zapotřebí zvolit jedince, kteří měli zkušenost $\mathrm{s}$ vyšším počtem zameškaných hodin. Vzhledem $\mathrm{k}$ tomu, že neexistuje jednotná definice absentérství vymezující přesný počet zameškaných hodin, která by mohla být uplatněna při identifikaci absentérů, bylo při volbě respondentů nutné specifikovat konkrétní podmínky. Celkem byla stanovena tři kritéria, z nichž musel žák splnit alespoň jedno, aby byl vybrán do výzkumného vzorku. Za prvé, žák uvádí, že nebyl nejméně z jednoho předmětu klasifikován z důvodu vysokého počtu zameškaných hodin, které nebyly důsledkem zdravotních či jiných legitimních problémů. Za druhé, žák přiznává zhoršenou známku z chování nebo podmínečné vyloučení ze studia kvưli neomluvené absenci zapřičiněné záškoláctvím. Za třetí, žák se sám pokládá za absentéra a přiznává, že chodil pravidelně za školu.

Po provedení selekce na základě tří zmíněných kritérií se počet respondentů zúžil na 15 žáků. $Z$ tohoto počtu jsme vyřadili čtyřri respondenty, kteří v průběhu diskusí v rámci ohniskových skupin neprojevili zájem o sdílení svých zkušeností $\mathrm{s}$ absentérstvím a odmítali se $\mathrm{k}$ této tematice vyjádřit. Finální počet respondentů tedy představuje 11 žáků ze čtyř středních odborných škol a středních odborných učilišt' v Jihomoravském kraji, kteří v průběhu svého vzdělávání na vyšším sekundárním stupni alespoň jedenkrát změnili střední školu. Všichni respondenti spolu s přestupem na jinou školu současně změnili i svůj obor studia (někteří i vícekrát než jednou), přičemž v některých prípadech se jednalo o přestup na zcela odlišný obor, v některých prípadech si naopak byly obory blízké (tabulka 1).

Tabulka 1 Charakteristika respondentů

\begin{tabular}{|c|c|c|}
\hline Respondent & Přechod mezi obory & Výzkumná technika \\
\hline Zdeněk & H: autolakýrník $\rightarrow$ H: opravář zemědělských strojů & \multirow[b]{2}{*}{ Ohnisková skupina 1} \\
\hline Marek & $\begin{array}{l}\text { H: kuchař-číšník } \rightarrow \text { H: opravář zemědělských strojů } \rightarrow \\
\text { L: mechanik elektrotechnik } \rightarrow \text { H: mechanik opravář } \\
\text { motorových vozidel }\end{array}$ & \\
\hline Tobiáš & $\begin{array}{l}\text { M: informační technologie } \rightarrow \text { L: mechanik elektrotechnik } \\
\rightarrow \text { L: mechanik elektrotechnik }\end{array}$ & Ohnisková skupina 2 \\
\hline Stanislav & M: hotelnictví $\rightarrow \mathrm{H}$ : truhlár̆ & \multirow{2}{*}{ Ohnisková skupina 3} \\
\hline Kryštof & $\mathrm{H}:$ automechanik $\rightarrow \mathrm{H}$ : strojní mechanik $\rightarrow \mathrm{H}:$ pokrývač & \\
\hline Roman & $\begin{array}{l}\text { H: elektromechanik pro zařízení a přístroje } \rightarrow \text { H: strojní } \\
\text { mechanik - zámečník }\end{array}$ & \multirow{2}{*}{ Ohnisková skupina 4} \\
\hline Matěj & $\begin{array}{l}\text { M: obalová technika } \rightarrow \mathrm{L}: \text { technik dokončovacího } \\
\text { zpracování tiskovin } \rightarrow \mathrm{H}: \text { umělecký truhlář a řezbář }\end{array}$ & \\
\hline Regina & L: kosmetické služby - vizážista $\rightarrow$ H: instalatér & \multirow{4}{*}{ Individuální rozhovory } \\
\hline Lucie & M: zdravotnické lyceum $\rightarrow$ L: kosmetické služby & \\
\hline Karel & $\mathrm{H}:$ puškař $\rightarrow \mathrm{H}:$ kuchař & \\
\hline Dan & M: management sportu $\rightarrow \mathrm{H}:$ kuchař & \\
\hline
\end{tabular}

Poznámka: Uváděná jména respondentů jsou pseudonymy; $\mathrm{H}$ - střední odborné vzdělání s výučním listem, $L$ - střední odborné vzdělání s odborným výcvikem a maturitou, $M$ - střední vzdělání s maturitní zkouškou. 


\subsection{Sběr dat}

Sběr dat proběhl v říjnu 2017 a byly při něm využity dvě výzkumné techniky - ohnisková skupina a hloubkový polostrukturovaný rozhovor. Za účelem sběru dat byly realizovány čtyři ohniskové skupiny s pěti až sedmi účastníky ve čtyřech školách. ${ }^{1}$ Hlavní potenciál této výzkumné metody tkví ve skupinové interakci, jejímž prostřednictvím získává výzkumník vhled do předmětu jeho zájmu (Morgan, 2001). Všechny ohniskové skupiny se konaly na půdě školy, kterou jejich účastníci navštěvovali, a průběh i řízení diskusí byly $v$ kompetenci hlavního moderátora, kterému pomáhal pomocný moderátor. Z ohniskových skupin byl pořizen jak audio-, tak i videozáznam, aby bylo při přepisu do elektronické podoby možné přiřadit jednotlivé výpovědi ke konkrétním žákům. Účastníci ohniskových skupin měli v rámci skupinové diskuse príležitost sdílet a srovnávat své zkušenosti a názory spojené s meziškolní mobilitou, přičemž již $v$ první ohniskové skupině se začalo $v$ jejich výpovědích postupně vynořovat téma absentérství. Ačkoli tato problematika pưvodně nebyla zahrnuta do schématu tazatelských otázek, začala spontánně zaznívat ze strany žáků již od první ohniskové skupiny, a proto se následně stala součástí tazatelského schématu. Každá ohnisková skupina trvala $v$ rozmezí 45-60 minut.

$\checkmark$ ohniskových skupinách se ukázalo, že přičiny meziškolní mobility, její průběh i důsledky představují poměrně citlivá témata, která se žáci mnohdy zdráhali sdílet se svými spolužáky a s ostatními žáky, které neznali. Z důvodu zřejmé choulostivosti dat byl nejdřive postupně snižován počet respondentů $v$ ohniskových skupinách a následně, v případě poslední skupiny respondentů, byla uplatněna druhá výzkumná technika - individuální hloubkové rozhovory. Z celkového počtu osmi polostrukturovaných hloubkových rozhovorů s osmi žáky byli pro předkládaný text zvoleni čtyři respondenti, jelikož právě oni zmiňovali své zkušenosti s absentérstvím a splňovali tak kritéria vzorkování. Vybráni byli na základě tři kritérií, která jsou shodná pro výběr respondentů z ohniskových skupin a jsou popsána v předchozím oddílu. U rozhovorů nebyla kromě tazatele a respondenta př́tomna žádná jiná osoba a všechny rozhovory probíhaly rovněž na půdě střední školy, kterou respondenti navštěvují. Každý rozhovor trval 25-35 minut, byl nahráván na diktafon a následně přepsán do elektronické podoby.

\subsection{Analytický postup}

Pro účely této studie byla provedena separátní analýza celého datového korpusu, přičemž byla využita technika otevřeného kódování (Švaříček, Šed'ová et al., 2007). Kódování bylo zaměřeno na datové fragmenty vypovídající o tom, jak žáci v rámci svého odpoutávání od školy vnímají své absentérství. Hledány byly významové jednotky, které byly dále vzájemně systematicky porovnávány za účelem nalezení podobností či rozdílů a vytvoření relevantních konceptů (srov. Řiháček \& Hytych,

1 V první škole byla realizována ohnisková skupina se sedmi žáky, ve druhé škole ohnisková skupina s pěti žáky, ve třetí škole se uskutečnily dvě ohniskové skupiny, a to se šesti a pěti žáky. 
88 2006; Strauss \& Corbinová, 1999). Vzhledem k tomu, že se diskuse v rámci ohniskových skupin odvíjejí jak od jedince, tak současně i od dynamiky dané skupiny jedinců (Morgan, 2001), analýza dat získaných v rámci ohniskových skupin probíhala na dvojí úrovni - nejdřive na úrovni jednotlivých skupin a poté konkrétních žákủ. Po přepisu a analýze komunikace $v$ rámci skupin žáků jako celku byly zvlášt’ analyzovány výpovědi každého respondenta, stejně jako tomu bylo $v$ př́padě individuálních rozhovorů.

Data přepsaná do elektronické podoby byla podrobena analýze nejdřive pomocí textového editoru. Po ukončení sběru byla data následně zpracována $v$ softwaru Atlas.ti, který sloužil jako podpora při snaze postupovat systematicky v procesu ukládání a organizace dat (srov. Konopásek, 2008). Po označení všech jednotek textu následovala jejich kategorizace a snaha o nalezení vztahů mezi jednotlivými kategoriemi. Abychom mohli identifikovat procesy a jejich produkty a porozumět, jak jsou určeny kontextuálními podmínkami, na otevřené kódování navázal druhý krok analýzy dat - vytváření logických řetězců a konstrukce prríčinných řetězců (Miles \& Huberman, 1994). Jednotlivé izolované události byly spojovány do logicky svázaných řetězců událostí, u nichž jsme dále identifikovali kauzální vazby a časovou posloupnost. Tímto postupem byly utvořeny tři kategorie týkající se nezájmu žáků o výuku, vrstevníků a tiché tolerance školy, které demonstrují skutečnost, že je absentérství komplexním jevem s celou řadou př́čin i důsledků.

\section{Výsledky}

Z důkladného třídění dat a jejich analýzy vyšly najevo prostřednictvím otevřeného kódování tři kategorie, kterým je věnována tato kapitola. Zmíněné kategorie představují príčiny, které žáky vedly k postupnému odpoutávání od školy, jehož jedním projevem bylo právě absentérství. Pro prezentaci poznatků jsme zvolili metodu „vyložení karet“. Tato metoda umožňuje převyprávět jednotlivé kategorie, jejich hlavní témata a obsah (více viz Švaříček, Šed'ová et al., 2007, s. 226-227), a umožnit tak čtenáři vhled do kauzality a provázanosti jednotlivých komponent v kategoriích.

\subsection{Učitelé a výuka jako příčiny absentérství}

Důvodem pro absenci žáků není, navzdory možným předpokladům, strach ze zkoušení, z písemného testu nebo hrozba špatné známky, ale skutečnost, že výuka a její obsah žáky nezaujaly natolik, aby v ní setrvali, nebo se na ni vůbec dostavili. Žáci nepovažují výuku za dostatečně atraktivní, jak uvádí Matěj: „Většina [učitelů] neuměla zaujmout a ty hodiny byly strašně nudné, tím pádem vždycky bylo lepší, když jsme [já a Roman] šli někam pokecat nebo takhle. "Podle Matěje je fádní výuka výsledkem přistupu učitelů, jelikož na nezajímavé hodiny pohliží jako na důsledek nízkých kompetencí učitelů k získání pozornosti třídy prezentovaným učivem. Náhradní program v podobě trávení času se spolužákem považoval za přitažlivější, a proto 
mu dal přednost před školní docházkou a účastí ve výuce. Učitelův styl výuky podle Matějových slov způsobil jeho nezájem o učivo, a proto nebyl ochotný se do dění ve škole zapojit. Roman rovněž sdílí názor, že se učitelům nedaří žáky nadchnout pro učení: „Nebavilo nás [absentéry] to, učitelé špatně učili. [...] No, neuměli to spíš tak podat, aby to bavilo všechny ostatní. “ Nuda se jeví jako hlavní spouštěč záškoláctví i u Romana, který vidí nezajímavou výuku rovněž v souvislosti s nevhodným přístupem učitele ve výuce a očekává, že by učitel měl zvládnout zaujmout bez výjimky všechny žáky, tedy i ty, které obsah výuky již sám o sobě příliš nezajímá. V opačném prípadě podle něj učitel selhal, a nudící se žák proto volí „zábavnější program“. Současně je však z jeho výpovědi patrné, že se nezájem netýká všech jedinců ve třídě, a proto si uvědomuje, že jeho negativní postoj nemusí sdílet i ostatní žáci ve třídě.

Kromě atraktivity učiva se jako indikátory toho, zda se žák rozhodne zameškat výuku, či nikoliv, objevily i subjektivně vnímané a hodnocené přínosnost a užitečnost učiva. Mají-li žáci pocit, že obsah výuky není dostatečně stimulační v oblasti jejich kognitivních nebo odborných dovedností, inklinují k absentérství. „Mě třeba co i hodně odpuzovalo z té školy, tak my jsme měli učitelku na angličtinu, [...] ona byla vyučená švadlena, měla roční kurz angličtiny a učila na maturitním oboru angličtinu. Polovina žáků uměla anglicky líp než ona, jenomže si to nenechala vysvětlit, “ uvádí Matěj, který považoval svoji přítomnost ve výuce za zbytečnou kvưli nedostatečné úrovni odborných znalostí učitelky. Má-li žák pocit, že jeho znalosti převyšují odbornou úroveň učitele daného předmětu, pak neočekává, že by výrazným zpưsobem mohl z výuky profitovat, a účast v této vyučovací hodině se mu jeví jako nadbytečná. O podobné zkušenosti, avšak v praktickém vyučování a v obsahové rovině výuky, hovoří i Stanislav: „Když mě to tam nebavilo [výuka v rámci oboru kuchař], tak jsem chodil prostě celej druhák za školu. [...] My jsme tam měli vařit a místo toho jsme třeba jenom utírali nádobí, dávali ho do myčky, a to je všechno. “Matěj i Stanislav se vyjadřují o absenci přínosnosti výuky, avšak zatímco u Matěje byly zdrojem jeho nespokojenosti nízké kompetence učitele, Stanislav hovoří spíše o nevyhovujícím obsahu výuky. Nepovažoval náplň praktického vyučování za adekvátní, a to především vzhledem k svému očekávání, které bylo původně zcela odlišné. Představoval si, že obsah praktické výuky bude spíše zaměřen na dovednosti, jejichž nácvik mu připadá ve zvoleném oboru zajímavější. Vzhledem k tomu, že realita byla odlišná a náplň praxe se mu jevila jako přiliš banální, nepředpokládal, že by zameškání výuky mělo jakýkoli vliv na výkon budoucího povolání v oboru. Absentérství podle Stanislava nevedlo k zameškání nácviku zásadních odborných dovedností, které by mohl v budoucnu postrádat.

Jak již bylo zmíněno $v$ teoretické části předkládané studie, nárưst počtu zameškaných hodin může indikovat skutečnost, že žák začíná pocit’ovat nespokojenost se svou původní volbou školy nebo studovaného oboru. K absentérství inklinují žáci $v$ momentě, kdy začnou přemýšlet nad profesní reorientací. „Asi v pololetí jsem nad tím [změnou oboru] začal přemýšlet... Já jsem tam fakt už ani nechodil ten půlrok. [...] Absence, ta byla velká,“ “ř́ká Karel, který kvůli neomluveným hodinám dostal trrídní důtku. S absentérstvím měl problém během zmíněného půlroku, na jehož 
90 počátku zjistil, že se mu obor jeho studia nezamlouvá. Nízká školní angažovanost a postupné odpoutávání od školy vedly $\mathrm{k}$ tomu, že Karel odmítal do školy docházet a být prítomen ve vyučovacích hodinách. Místo efektivního řešení vzniklého problému, kterým byla špatná volba vzdělávací dráhy, tedy sám volil neefektivní cestu zameškávání výuky. Žák v takovémto př́padě volí únik ze situace, která se mu jeví jako nekomfortní - tj. $z$ výuky $v$ daném oboru -, a to proto, že se mu absentérství zdá jako nejsnazší a potažmo nejrychlejší cesta splňující jeho hlavní cíl, vyhnout se výuce v oboru, jejž nadále studovat nechce. Je zřejmé, že žák v dané situaci neřeší možné důsledky a dlouhodobé dopady svého jednání.

\subsection{Role vrstevníků}

Rozhodnutí žáka neúčastnit se výuky, tedy na ni záměrně nepřijít anebo opustit školu před jejím konáním, bývá často podporováno stejným rozhodnutím učiněným ze strany jeho spolužáka či skupiny spolužáků. Vrstevníci v tomto ohledu sehrávají kličovou roli. „Kamarád mně řekl: ,Nechceš se na to dneska vykašlat?‘ Tak jsem se na to vykašlal. Prošlo mně to jednou, prošlo mně to podruhé a pak najednou mi začala naskakovat absence, takže v prváku jsem měl absenci, ,enka“ z x předmětů, “ uvádí Kryštof, podle něhož bylo zameškání výuky primárně iniciováno jeho spolužákem, který učinil hlavní rozhodnutí týkající se záškoláctví. Teprve až na jeho základě se Kryštof rozhodl výuku úmyslně zameškat a díky své plnoletosti si absence mohl omluvit sám. Jeho rozhodnutí tak podporovala právě skutečnost, že omluvení vlastních absencí po osmnáctém roce věku je proces poměrně nenáročný, nevyžadující oslovení či angažování jiných osob kromě žáka.

Zameškání výuky a záškoláctví mohou být činy jednotlivce, dvojice anebo skupiny více žáků. Zatímco Kryštof chodil za školu se svým spolužákem, a tvořili tak dvojici absentérů, Dan patřil do čtyřčlenné skupiny, jež výuku zameškávala společně: „Vlastně jsme vytvořili takovou partu čtyř kluků, kteří tam [do školy] moc nechodili.“ Záškoláctví tedy představovalo jakýsi sdílený zážitek, společný čin, jehož se účastnila celá skupina. Ve větší skupině záškoláků se může zvyšovat zdánlivý dojem toho, že žák sám nenese odpovědnost za tento čin, poněvadž se záškoláctvím provinili i jeho kamarádi, nejen on sám. $Z$ toho také plyne možný pocit žáka ohledně sdílení př́padného trestu. Sankce za záškoláctví totiž nebude platit pouze pro daného žáka, nýbrž ve stejné situaci se ocitnou i jeho spolužáci a řešit ji budou nuceni všichni provinilí jedinci.

Je-li prvotní plán týkající se záškoláctví iniciován druhou osobou, žák zpětně tuto situaci hodnotí jako podlehnutí a podřizení se svému okolí. Jak uvádí Matěj: „Já jsem se nechal stáhnout jinýma lidma. “ Ačkoliv o vinících hovoří v množném čísle, na vině je podle něj především jeden konkrétní spolužák, který s myšlenkou záškoláctví přišel jako první. Za problematickou tedy žák považuje $v$ tomto směru skutečnost, že s daným jedincem utvořil určitou alianci, která pak vedla $\mathrm{k}$ jeho problémům se školní docházkou. Jako spouštěč nárůstu zameškaných hodin může být shledáván i nástup do stejné školy se spolužákem majícím obdobný přistup ke školní docházce. „[My] 
jsme šli [na předchozí školu] s kamarádem, takže to nedopadlo moc dobře, protože jsme měli taky absence a nechodili jsme tam spolu, chodili jsme za školu, “ ríká Roman, jenž nastoupil středoškolská studia společně se svým vrstevníkem a hodnotí toto rozhodnutí jako klíčové v souvislosti se svými problémy se záškoláctvím.

Zameškáním výuky vzniká žákům „volný“ čas, který tráví podle svých vlastních preferencí. Jedná se o aktivní trávení času, anebo, jako v prípadě Tobiáše, se vyplňování času za školou děje spiše pasivnější formou: „Já jsem si vždycky zašel někam do KFCéčka. Pak jsem vždycky pozdravil spolužáky, jak odchází z praxí.“ Tato činnost, tedy sezení v rychlém občerstvení KFC, se jeví spiše jako nahodilá alternativa, díky niž byl Tobiáš stále $v$ blízkosti spolužáků, a žádná zásadní změna tak z této volby pro náplň jeho dne neplynula. Tobiášovo rozhodnutí naznačuje snahu vyplnit čas př́ijemnějším způsobem, nežli činí jeho spolužáci, a zároveň se od nich př́liš nedistancovat. Vzhledem $k$ tomu, že se před spolužáky Tobiáš své záškoláctví nesnažil skrývat, mohlo jít také primárně o projev určité rebelie, kterou chtěl dát před svými vrstevníky najevo. Čas strávený v rychlém občerstvení představuje naprosto odlišnou formu trávení času místo výuky, než kterou zmiňují další tři žáci - ti nejčastěji volí aktivity, jimž se věnují i ve svém volnu, považují je za př́ijemné a při pravidelné školní docházce by jim nemohli věnovat tolik času. „Radši jsme se domluvili, že si půjdeme zahrát fotbal. Třeba místo v pondělí na osmou jsme přišli na desátou,“ ř́ká Dan, jehož záškoláctví se spolužáky probíhalo na základě předchozí domluvy na konkrétní činnosti, kterou se skupina rozhodla vyplnit dobu výuky. Náhradní program je $v$ takovém př́padě předem naplánovaný a záškoláctví se stává jakýmsi vedlejším důsledkem touhy věnovat se oblíbené činnosti - u Dana a jeho spolužáků fotbalu. I Zdeněk preferoval v době výuky sportovní vyžití: „Věnoval jsem se spíš fotbalu a sportu. "Karel si naopak až na základě vzniklého volného času našel novou zálibu, které se místo školy věnoval: „Tak já jsem začal kovařit. Našel jsem si kurz. Začalo mě to bavit. Já jsem to viděl $v$ televizi. [...] Na ten půlrok jsem si to zaplatil a chodil jsem do Znojma na kurz kovařiny. “ Volný čas Karel trávil rozvíjením svých dovedností v řemeslu, jež jej zaujalo. Jeho nezájem o výuku tedy sice vedl k záškoláctví, ale rovněž i $k$ produktivní činnosti v nově zvolené oblasti profesního zájmu. Ačkoli se jedná o ojedinělý prípad, Karlův př́stup dokazuje, že absentérství a zameškané hodiny nemusí nutně indikovat pouze skutečnost, že se žák vyhýbá svým povinnostem, ale může značit i volbu činnosti, kterou žák upřednostňuje a považuje ji za smysluplnější alternativu ve srovnání se školní výukou.

\subsection{Tichá tolerance absentérství}

Pravidla týkající se povinné školní docházky často nejsou ve středních školách nastavena tak, aby se prípadnému absentérství snažila předcházet, jelikož chybí následná kontrola dodržování těchto pravidel. „Oni [učitelé] tam vlastně po nás vůbec nechtěli omluvenky, takže jsme si mohli odejít, kdy jsme chtěli, a toho jsme zneužívali,“ říká Dan. Nemá-li žák povinnost komukoliv uvádět důvod své absence a zodpovídat se za zmeškání výuky, může to vyvolat falešný předpoklad, že záškoláctví není zá- 
92 važným přestupkem a nemá zásadní vliv na jeho vzdělávací dráhu. Žáci v souvislosti se školní docházkou nemají ze strany školy jasně stanoveny pomyslné mantinely, ve kterých by se měli držet. Navíc, jak uvádí Tobiáš, žáci často zkouší, zda a do jaké míry je škola v kontrole dodržování pravidel důsledná: „Dojdete do nové školy a musíte objevovat hranice. “ $V$ př́padě, že zmíněné hranice a adekvátně nastavená pravidla chybí, neočekávají žáci ani sankce, jež by jim hrozily při jejich nedodržení. Př́lišná benevolence může zpưsobit nejasnost při přemýšlení nad tím, jaké chování bude školou i jejími učiteli akceptovatelné a jaké už bude za hranou.

Ačkoli ve středních školách bývá nepř́tomnost žáka zpravidla evidována, v některých prípadech škola dlouhodobé a frekventované absence $v$ jejich průběhu př́liš neřeší a nezajímá se o jejich příčiny. Stanislav zmiňuje svoji několikaměsíční absenci: „[Já] jsem se dostal do druháku, byl jsem tam první den a pak jsem se tam neukázal. Až třeba na nový rok jsem se ukázal na dvě hodiny a zas jsem šel pryč. " Stanislavovi podle jeho slov nic nebránilo $v$ tom, aby nebyl dlouhodobě ve výuce př́tomen, což potvrzuje skutečnost, že ze strany školy $v$ tomto směru chybí adekvátní kontrola. Zdeněk se rovněž přiznává $k$ tomu, že trávil více času mimo výuku nežli v ní: „Já jsem tam nechodil. Já jsem tam byl ve škole šestkrát za celý rok." Stejně tak Marek: „Tam jsem potom druhé pololetí přišel, myslím, jednou na tělocvik, zakopat si.“ Ačkoli frekvence a rozsah absencí žáků vybočovaly z normálu, jejich jednání nebylo ze strany školy nijak komentováno a zůstalo bez reakce. Ta přichází až spolu s vysvědčením, jelikož z vysokých absencí, které navíc nejsou omluvené, plyne pro žáka určitá forma sankce v podobě napomenutí, třídní či ředitelské důtky, podmínečného vyloučení nebo sniženého stupně $z$ chování. $V$ průběhu školního roku se však tato problematika jeví jako školou opomíjená.

S odloženým a pasivním řešením problému absentérství ze strany školy souvisí skutečnost, že žák si závažnost svého absentérství uvědomí až ve chvíli, kdy je př́liš pozdě na to, aby šlo předejít závažnějším důsledkům. $V$ případě, že má žák absence omluvené, tento okamžik zpravidla nastává, když je neklasifikován, a to i z několika předmětů zároveň, jako tomu bylo u Lucie: „Pak už jsem tam fakt nechtěla chodit, že už jsem se na to vykašlala. No, a pak jsem měla na konci roku vlastně deset ,enek ‘ [neklasifikovaná z deseti předmětů, pozn. autorů].“ Přesáhne-li počet zameškaných vyučovacích hodin určitý limit, jenž je obvykle stanoven na dvacet procent výuky $v$ daném předmětu $\mathrm{v}$ jednom pololetí, pak není žák z předmětu klasifikován a místo známky získává na konci pololetí $N$ neboli „enko“, jak je žáky neklasifikování neformálně označováno. Pro postup do dalšího ročníku Lucie musela $z$ více než poloviny předmětů složit opravnou zkoušku, což představuje velké množství učiva a značný objem času stráveného učením během letních prázdnin: „Dělala jsem je [opravné zkoušky] v létě a fakt jsem se na to učila. Byla jsem z toho úplně ve stresu. Říkala jsem si, proč jsem byla tak blbá, proč jsem tam nechodila. “ Lucie si závažnost svého jednání uvědomila až ve chvíli, kdy musela vykonat opravné zkoušky, a byla tedy konfrontována s reálným dopadem svého absentérství. Neklasifikování tedy vede k prvnímu uvědomění si dopadu vyhýbání se výuce a závažnosti vzniklé situace. Druhé, zásadnější a intenzivněji vnímané poznání reálných důsledků nastává, kdy je 
žák nucen obětovat vlastní volný čas přípravě a vykonání opravných zkoušek. Svého jednání tak zpětně lituje.

Ačkoli někteří žáci volili otevřený způsob jednání a na rovinu vyučujícímu sdělili svůj záměr nenavštěvovat výuku, učitelé se ani v tomto prípadě absentérství nijak nesnažili zabránit, a dokonce je akceptovali. „Jak jsem přestával chodit to druhé pololetí, tak nějak jsem to tam vysvětlil. Jsme si promluvili mezi čtyřma očima [s paní reditelkou] a ona to jaksi pochopila a ten pưlrok mě v podstatě omlouvala. Držela mě tam, “ ríká Marek. V jeho př́padě se nejenže jedná o toleranci jeho absentérství ze strany ředitelky školy, ale současně o její cílenou snahu zamezit důsledkům vyplývajícím ze zameškaných hodin. Uvedeným přístupem ředitelka podporovala posunování Markových pomyslných hranic a přispívala $\mathrm{k}$ tomu, že nabýval falešného dojmu o nulových dopadech svého záškoláctví. Tato tendence se objevila nejen v príipadě neplnění školní docházky, ale rovněž při neplnění dalších školních povinností, o kterých hovoří Regina: „Ona [trrídní učitelka] už pak věděla, jak jsem fakt jenom podepsala test, at' už mně dají pokoj, a spala jsem tam ve škole, třeba prospala tři hodiny $v$ kuse, $a$ oni už věděli, že to jde do háje a že je to zbytečné se mnou něco řešit. [Já] jsem k tomu měla takový arogantní přistup. “I přesto, že žákyně spolu s vysokým počtem zameškaných hodin projevuje svůj nezájem o výuku již delší dobu, učitelé nevyvíjejí snahu zjistit zdroj jejího postoje. Reginino chování lze označit nejen jako rebelství, které je pro adolescenty typické, ale rovněž jako absentérství odehrávající se ve třídě (viz kapitola Školní absentérství), jelikož se v průběhu výuky věnovala činnostem, které s učivem či vyučovaným předmětem nijak nesouvisejí.

\section{Diskuse}

Výpovědi respondentů ukázaly, že nepravidelná školní docházka a záškoláctví jsou spojeny s procesem odpoutávání od školy (school disengagement), jenž má zásadní vliv na vzdělávací dráhu jedince (Archambault et al., 2009; Finn, 1989; Rumberger \& Larson, 1998). Tento koncept se $v$ literatuře objevuje především $v$ kontextu teorií o předčasných odchodech ze vzdělávání (drop-out; Archambault et al., 2009), a to jako proces, který může vyústit $v$ předčasné ukončení formálního vzdělávání jedince. Opačná situace odpoutávání od školní výuky se označuje jako angažovanost $v$ oblasti školní výuky (school engagement) a bývá ovlivněna prospěchem žáka, jeho zkušenostmi se vzděláváním, postoji, ale i rodinou a komunitou, z níž žák pochází (Rumberger \& Larson, 1998). Akademicky neangažovaní žáci, tedy ti, kteří se nacházejí v procesu odpoutávání od školy, jsou méně vytrvalí ve snaze zvládat školní zátěž (Wang et al., 2018), a proto lze očekávat jejich tíhnutí k absentérství. $v$ případě našeho výzkumu proces odpoutávání vyústil $v$ odchod $z$ dané školy, žáci však po reorientaci své vzdělávací dráhy ve studiu jiné školy opět ve vzdělávání pokračují. Proces odpoutávání od školy může probíhat dvěma způsoby, a to bud' jako model frustrační, anebo participativně identifikační (Finn, 1989). Frustrační model staví na školní neúspěšnosti žáka, která zapř́čiňuje jeho nega- 
94 tivní postoj ke škole a odmítání školní docházky. Na druhou stranu v participativně identifikačním modelu hraje hlavní roli nízká míra identifikace jedince se školou, která je zapř́ičiněna nedostatečnými akademickými výsledky. Vzhledem k tomu, že v absentérství žáků hrál hlavní úlohu především nezájem o školní výuku, nikoli nízké studijní výsledky či školní neúspěšnost (ty spíše představují důsledek jednání žáků), podle Finnova (1989) dělení procesu odpoutávání od školy se jednání žáků odehrávalo $v$ rámci participativně identifikačního modelu. Oba modely však připouští projevy absentérství žáka a současně i nevhodné chování, kterého si učitelé všímají a individuálně na ně reagují. Dle uvedeného autora se postoj ke škole po přestupu do jiné školy může změnit, stejně jako tomu bylo u respondentů této studie.

Záškoláctví se na samém začátku žákům nejeví jako zásadní problém, jelikož zameškáním výuky dosáhnou svého cíle, tedy vyhnou se výuce a netráví svůj čas ve škole. $V$ krátkodobé rovině navíc $z$ absentérství nevyplývají žádné zásadní problémy či sankce, a proto žáci nepocit'ují žádné zábrany a $v$ absentérství dále pokračují. $V$ konečném důsledku je však situace zcela opačná. $Z$ výsledků naší studie je patrné, že se absentérství žáka neobejde bez závažných důsledků, avšak žák je s nimi konfrontován až v delším časovém horizontu, tedy v době, kdy již nelze vzniklý problém jednoduše napravit a zameškané hodiny ovlivňují průchod žáka jeho vzdělávací dráhou. $V$ tomto ohledu lze předjímat, že pouhá šance na vzdělávání žáků s vysokým počtem absencí nestačí - žáci potřebují hranice nebo určité mantinely, které jim pomohou lépe vyhodnotit, zda je jejich jednání prípustné, či nikoliv, a zda se vůbec $\mathrm{k}$ tomuto jednání uchýlí. Vysoká absence se negativně projevuje ve studijních výsledcích žáka, jelikož na něj klade zvýšené nároky $v$ podobě dodatečných písemných testů nebo rozdílových zkoušek, a představuje tak rizikový faktor školní neúspěšnosti. Zmíněná skupina žáků proto tvoří ohroženou skupinu, která ze strany školy potřebuje podporu $v$ co nejvyšší míre.

Je současně zřejmé, že školní absentérství lze považovat za první indikátor skutečnosti, že si žák nezvolil vhodnou vzdělávací dráhu (srov. Önder, 2017), a proto se nárůst zameškaných hodin může objevit ve chvíli, kdy se žák rozhoduje - anebo je již rozhodnutý - ve vzdělávání $v$ dané škole nadále nepokračovat a změnit jak vzdělávací instituci, tak i obor studia. Před přestupem do jiné školy žák s vysokým počtem zameškaných hodin nepocit'uje potřebu do původní školy nadále docházet, a to ani $v$ př́padě, že není rozhodnutý o dalším směřování v rámci svého studia. Je tomu tak proto, že prítomnost ve výuce mu přijde zbytečná a postrádající smysl, jelikož důvodem přestupu bývá často nespokojenost $s$ oborem a nenaplnění představ žáka o výuce $v$ rámci studovaného oboru. To nás vede $k$ podobnému závěru, jaký učinili autoři Şahinová et al. (2016), považující absentérství za jeden z nejzákladnějších indikátorů toho, do jaké míry jsou ve škole naplňovány vzdělávací potřeby žáků.

Zjištění Ishaka a Finové (2013) poukazují na klíčovou roli učitelů při řešení problémů žáků spojených s absentérstvím. Výsledky předkládané studie však odhalují $v$ tomto směru nedostatky spočívající $v$ nízké míre intervence, která by směřovala $\mathrm{k}$ redukci počtu zameškaných vyučovacích hodin. Přístup školy $v$ textu označujeme 
tichá tolerance, nebot' škola nevyvijí potřebnou snahu o sekundární prevenci před dalšími projevy absentérství žáků. Vzhledem k tomu, že je dokázáno, že nedostatek pozornosti ze strany učitelů zvyšuje u žáků absentérů jejich tendenci dále zameškávat výuku (Ishak \& Fin, 2013), zájem učitelů se v tomto směru jeví klíčovým. Škola vyjadřuje tichou toleranci směrem $k$ absentérům i přesto, že problémy s absentérstvím lze, na rozdíl od jiných druhů problematického chování, okamžitě odhalit. Tato skutečnost může poskytnout pedagogickým pracovníkủm výhodu a umožnit jim reagovat na absentérství žáka již v momentě, kdy jsou patrné jeho nepravidelná docházka a změna v počtu zameškaných hodin. Spiše než rozvolněnost pravidel školy se jako hlavní problém jeví nedostatečná důslednost při kontrole jejich dodržování. Přesnou formu omluvenek a pravidla pro jejich předkládání stanovuje školní rád, obvykle je žáci předkládají s podpisem svého zákonného zástupce či lékaře. V okamžiku, kdy žák dosáhne plnoletosti, při omlouvání svých absencí souhlas ani podpis rodičů nepotřebuje a omlouvání zameškaných hodin je již zcela v jeho kompetenci. $S$ tímto souvisí i zjištění, že pro žáky absentéry nehraje zásadní roli postoj rodičů $\mathrm{k}$ jejich školní docházce. Rodiče a jejich názory na absentérství svých dětí totiž žáci vůbec $v$ rozhovorech nezmiňovali. $Z$ toho důvodu lze usuzovat, že potřebné mantinely nemusí mít žáci nastaveny nejen ve škole, ale ani ze strany rodičů, a o to více je žádoucí, aby byla škola při nastavování pravidel a zpưsobech kontroly jejich dodržování dưrazná. Za účelem řešení problematiky absentérství a zameškávání výuky by měla intervence probíhat ve všech zmíněných úrovních, jelikož, jak ukazuje Sheldonova (2007) studie, spolupráce mezi rodinou, školou a komunitou žáka zlepšuje jeho školní docházku.

\subsection{Limity výzkumu a návrhy pro další zkoumání}

Prvním limitem této studie je skutečnost, že prezentuje dílčí poznatky z šířeji koncipovaného výzkumu zaměřeného na meziškolní mobilitu. Problematika absentérství si však vzhledem ke své rozšîrenosti a závažnosti zasluhuje vlastní výzkumné šetření zaměřené pouze na tuto konkrétní oblast $s$ cílem odhalit veškeré kontextuální proměnné promítající se do absentérství žáků a jeho důsledků. Další významný limit představuje populace žáků, z níž byli voleni jedinci tvořící výzkumný vzorek. Je důležité zdůraznit a znovu připomenout skutečnost, že respondenty předkládaného výzkumu jsou žáci, kteři v průběhu svého vyššího sekundárního vzdělávání alespoň jednou změnili školu. Jejich hlavním atributem je tedy přechod mezi středními školami a často rovněž mezi studovanými obory. Žáci zahrnutí v naší studii navíc do nové střední školy přecházeli mnohdy ze vzdělávacích institucí s vysokou mírou meziškolní mobility. Je tedy zřejmé, že se jedná o velice specifickou skupinu žáků středních odborných škol a středních odborných učilišt' v Jihomoravském kraji, a právě již zmíněná specifičnost znemožňuje jakékoli zobecňování výsledků této studie na širší populaci. Nemožnost srovnat naše zjištění s výsledky z jiných částí České republiky nebo z odlišných typů škol kvưli absenci podobných výzkumů však poukazuje na evidentní research gap. Realizace dalších výzkumných šetření na téma absentérství, 
96 které by se zaměřily na ostatní kraje České republiky, odlišné věkové skupiny žáků nebo úrovně vzdělávání, by znamenaly významný krok k detailnějšímu chápání této oblasti. $V$ rámci analýzy dat se navíc ukázalo, že některé tematické oblasti nebyly naším výzkumem dostatečně rozkryty. Budoucí bádání by mohlo být zaměřeno např. na význam vrstevnických vztahů žáků absentérů, postoj školy a pedagogického sboru $\mathrm{k}$ absentérství, roli rodičů $v$ žákově zameškávání výuky a další témata.

Co se týká důvodů vedoucích $\mathrm{k}$ absentérství žáků, je zapotřebí znovu zmínit skutečnost, že $v$ průběhu sběru dat nezazněly všechny, a proto nejsme schopni předložit jejich kompletní a vyčerpávající seznam. Kvưli rozhodnutí některých respondentů nesdílet s námi své zkušenosti existují důvody pro zameškávání školní výuky, které nám zůstaly skryty, protože o nich žáci odmítli hovořit. Z metodologického hlediska se jako prevence proti získání takovýchto cenzurovaných výpovědí žáků při zkoumání absentérství nabízí opakovaný návrat do výzkumného terénu a opakované rozhovory za účelem získání větší důvěry respondentů, a tedy i většího množství a hloubky dat. Tento postup se nám jeví jako nevyhnutelný, jelikož je zřejmé, že se jedná o citlivé téma, které vyžaduje citlivý př́stup výzkumníka. Věříme však, že by výzkumné šetření i přes stejné téma přineslo $v$ závislosti na různých respondentech a rozmanitém časoprostoru pestrá data, a to díky silně specifické cílové skupině respondentů. Adolescentní věk, (ne)závislost na rodičích, socioekonomické zázemí rodiny, bydliště žáka apod. jsou významné atributy, které se odrážejí ve vzdělanostních aspiracích a postoji ke školní docházce, potažmo absentérství.

S charakteristikou výzkumného vzorku a absencí některých dat se navíc pojí otázka, do jaké míry se $v$ předkládané studii podařilo obsáhnout téma absentérství ze žákovské perspektivy. Vzhledem $\mathrm{k}$ tomu, že naše výzkumné šetření zahrnulo pouze žáky určitého typu, tzn. jedince, kteří podstoupili změnu školy, chybí perspektiva ostatních žáků, tedy těch, kteří sice problémy se zameškáváním výuky mají, avšak meziškolní mobilita se jich netýká. Od této skutečnosti se odvíjí možná homogenita $\checkmark$ charakteristikách jednotlivých žáků, která je ještě podtržena omezením na jednu část České republiky a určitý typ středních škol. I přestože tak není zcela zajištěna rozmanitost, co se týká např. socioekonomického prostředí rodin žáků nebo vzdělanostních aspirací, v kvalitativním přístupu se nám jeví jako př́nosné zprvu podrobně prozkoumat jednu homogenní skupinu respondentů v rámci cílové skupiny a až následně se zaměřit na jinou skupinu respondentů, anebo jejich okruh rozšírít. Vzhledem $\mathrm{k}$ tomu, že se však cílová skupina nachází v adolescentním věku, ve kterém u člověka teprve dochází ke krystalizaci sebevědomí či vlastních postojů, lze se právem domnívat, že některé informace zůstaly nevyřčeny, jiné mohly být zkresleny neochotou jakkoli se vyjadřovat $\mathrm{k}$ tématu absentérství. Zmíněná skutečnost přispívá k tomu, že nelze hovořit o vyčerpávajícím prozkoumání tématu absentérství, avšak jako první výzkumné šetření zaměřené na téma absentérství lze získaná data považovat za velice významná a směrodatná pro další výzkum.

Uchopení problematiky absentérství z perspektivy žáků, byt’ volených ze značně specifické skupiny jedinců, lze považovat za přednost předkládané studie, a to díky vysokému potenciálu odhalení skrytých témat, ale současně i za limit, jelikož 
aktuálně chybí vyjádření aktérů stojících na pomyslné „druhé straně“, tedy pedagogických pracovníků a rodičủ žáků. Názory a postoje žáků mohou být značně subjektivní, a proto by bylo vhodné budoucí výzkum koncipovat tak, aby v něm bylo možné získat náhled všech aktérů zahrnutých do tohoto procesu a jejich vyjádření ke konkrétním tématům z oblasti školního absentérství. Jako další krok na výzkumném poli tedy navrhujeme zaměření na konkrétní případy, tedy vícečetnou případovou studii, a vícezdrojový sběr dat, který by vedl k odhalení perspektivy žáků, učitelů, ředitelů, výchovných poradců a školních psychologů, a to prostřednictvím opakovaných hloubkových rozhovorů, ohniskových skupin a analýzy pedagogických a dalších dokumentů žáka.

\section{Závěr}

Předložená studie se věnuje absentérství u žáků středních odborných škol a středních odborných učilišt'. Jejím cílem bylo zjistit a popsat, jak vnímají své absentérství žáci, kteři přestupují do jiné střední školy. Je nutné zmínit, že problematika týkající se neplnění školní docházky představuje v českém kontextu neprobádané téma, a to i presto, že se tento druh rizikového chování ve vyšší míře objevuje mezi žáky středních škol v České republice (ČŠl, 2017). Výsledky výzkumů z jiných zemí navíc naznačují negativní dopad absentérství na vzdělávací dráhu jedince (např. Kearney \& Graczyk, 2014; Önder, 2017; Șahin et al., 2016).

Absentérství je fenomén, na který žáci s dlouhodobými problémy se školní docházkou nahližejí jako na určitou formu úniku ze školní výuky, již podle svých slov považují za fádní, nezajímavou nebo nepř́nosnou. Vyučování se žáci absentéři nechtějí účastnit, jelikož se neodehrává podle jejich představ a o jeho obsah neprojevují zájem. Na základě tohoto př́stupu volí alternativní program, kterým nahrazují svoji nepř́tomnost ve škole a který si často plánují předem. Zameškávání výuky tito žáci považují za legitimní chování, jelikož pro ně představuje určitý náhradní plán, který si museli nutně zvolit z důvodu nevyhovující školní výuky. Předem však nepřemýšlejí nad možnými důsledky svého chování nebo nad tím, že by zameškané hodiny mohly zásadně ovlivnit jejich působení v dané škole, potažmo ve škole, na kterou plánují přestoupit.

Další závažné zjištění předkládané studie se týká role vrstevníků a spolužáků $\checkmark$ procesu absentérství. Zameškávání výuky se nejeví pouze jako rozhodnutí jednotlivce, nýbrž jako rozhodnutí více žáků, kteří se společně místo školní docházky věnují jiným, pro ně subjektivně příjemnějším činnostem. Absentérství se tak stává sdílenou zkušeností dvojice nebo skupiny žáků, kteří za tímto účelem vytvářejí určitou alianci a společně plánují čas strávený mimo vyučování. Závěry naší studie naznačují, že v oblasti absentérství hrají spolužáci žáka významnou roli, a potvrzují tak výsledky kvantitativního šetření provedeného ve Finsku u žáků středních škol, které dokazuje, že žáci mají tendenci nechat se ovlivnit svými vrstevníky ve své školní angažovanosti a jmenovitě v jejich tendenci k záškoláctví (Wang et al., 2018). Autoři 
98 navíc zjistili, že žáci mají sklon vybírat si nové přátele $z$ řad těch, kteří v podobné míře inklinují k absentérství, což podtrhuje význam složení a formování školní třídy.

Věŕme, že se nám touto studií podařilo přispět do diskuse o závažnosti absentérství, o jeho vlivu na vzdělávací dráhu jedince a o roztřŕštěnosti v oblasti pravidel týkajících se školní docházky žáků a kontroly jejich dodržování ve středních školách. Dále doufáme, že rámcové poznatky, $k$ nimž jsme $v$ našem výzkumu dospěli, otevřou prostor pro další výzkum této oblasti.

\section{Literatura}

Archambault, I., Janosz, M., Fallu, J.-S., \& Pagani, L. S. (2009). Student engagement and its relationship with high school dropout. Journal of Adolescence, 32(3), 651-670.

Balfanz, R., \& Byrnes, V. (2012). The importance of being in school: A report on absenteeism in the nation's public schools. Baltimore: John Hopkins University Center for Social Organization of Schools. Dostupné z https://www.attendanceworks.org/importance-school-report -absenteeism-nations-public-schools

Barlow, J., \& Fleischer, S. (2011). Student absenteeism: Whose responsibility? Innovations in Education and Teaching International, 48(3), 227-237.

Birioukov, A. (2016). Beyond the excused/unexcused absence binary: Classifying absenteeism through a voluntary/involuntary absence framework. Educational Review, 68(3), 340-357.

Česká školní inspekce. (2016). Kvalita a efektivita vzdělávání a vzdělávací soustavy ve školním roce 2015/2016. Výroční zpráva České školní inspekce. Praha: Čšl.

Česká školní inspekce. (2017). Kvalita a efektivita vzdělávání a vzdělávací soustavy ve školním roce 2016/2017. Výroční zpráva České školní inspekce. Praha: Čšl.

Česká školní inspekce. (2018). Kvalita a efektivita vzdělávání a vzdělávací soustavy ve školním roce 2017/2018. Výroční zpráva České školní inspekce. Praha: ČŠl.

Česká školní inspekce. (2019). Kvalita a efektivita vzdělávání a vzdělávací soustavy ve školním roce 2018/2019. Výroční zpráva eské školní inspekce. Praha: Čšl.

Finn, J. D. (1989). Withdrawing from school. Review of Educational Research, 59(2), 117-142.

Fremont, W. P. (2003). School refusal in children and adolescents. American Family Physician, 68(8), 1555-1560.

Gottfried, M. A. (2014). Chronic absenteeism and its effects on students' academic and socioemotional outcomes. Journal of Education for Students Placed at Risk, 19(2), 53-57.

Gump, S. E. (2006). Guess who's (not) coming to class: Student attitudes as indicators of attendance. Educational Studies, 32(1), 39-46.

Hlaváčová, P. (2015). Záškoláctví: možnosti řešení z pohledu školního psychologa. Školní poradenství v praxi, 2(3), 32-35.

Hunt, M. H., Meyers, J., Davies, G., Meyers, B., Grogg, K. R., \& Neel, J. A. (2002). Comprehensive needs assessment to facilitate prevention of school drop out and violence. Psychology in the School, 39(4), 399-416.

Ishak, Z., \& Fin, L. S. (2013). Truants' and teachers' behaviors in the classroom. Procedia Social and Behavioral Sciences, 103, 1228-1237.

Jonasson, Ch. (2011). The dynamics of absence behaviour: Interrelations between absence from class and absence in class. Educational Research, 53(1), 17-32.

Kearney, C. A. (2008). School absenteeism and school refusal behaviour in youth: A contemporary review. Clinical Psychology Review, 28(3), 451-471.

Kearney, C. A., \& Graczyk, P. (2014). A response to intervention model to promote school attendance and decrease school absenteeism. Child \& Youth Care Forum, 43(1), 1-25.

Konopásek, Z. (2008). Making thinking visible with Atlas.ti: Computer assisted qualitative analysis as textual practices. Forum Qualitative Sozialforschung / Forum: Qualitative Social 
Research, 9(2), Art. 12. Dostupné z http://www.qualitative-research.net/index.php/fqs /article/view/420/911

Miles, M. B., \& Huberman, A. M. (1994). Qualitative data analysis: An expanded sourcebook. Thousand Oaks: Sage Publications.

Morgan, D. L. (2001). Ohniskové skupiny jako metoda kvalitativního výzkumu. Boskovice: Sdružení SCAN.

Önder, E. (2017). Student absenteeism in secondary education, absenteeism-related school practices and recommended policies. Education and Science, 42(190), 361-378.

Petrák, M. (2012). Záškoláctví z perspektivy státního zástupce. Řízení školy: odborný měsíčník pro ředitele škol, 9(10), 18-20.

Průcha, J., Walterová, E., \& Mareš, J. (2009). Pedagogický slovník. Praha: Portál.

Rumberger, R. W., \& Larson, K. A. (1998). Student mobility and the increased risk of high school dropout. American Journal of Education, 107(1), 1-35.

Řiháček, T., \& Hytych, R. (2006). Metoda zakotvené teorie. In I. Čermák, T. Řiháček, \& R. Hytych (Eds.), Kvalitativní analýza textů: čtyři př́stupy (s. 44-74). Brno: Masarykova univerzita.

Sahin, S., Arseven, Z., \& Kılıc, A. (2016). Causes of student absenteeism and school dropouts. International Journal of Instruction, 9(1), 195-210.

Sheldon, S. B. (2007). Improving student attendance with school, family, and community partnership. The Journal of Educational Research, 100(5), 267-275.

Stempel, H., Cox-Martin, M., Bronsert, M., Dickinson, M., \& Allison, M. A. (2017). Chronic school absenteeism and the role of adverse childhood experiences. Academic Pediatrics, 17(8), 837-843.

Strauss, A. L., \& Corbinová, J. (1999). Základy kvalitativního výzkumu. Brno: Albert.

Sutphen, R. D., Ford, J. P., \& Flaherty, Ch. (2010). Truancy intervention: A review of the research literature. Research on Social Work Practice, 20(2), 161-171.

Svobodová, L. (2012). Skryté záškoláctví. Řizení školy: odborný měsíčník pro ředitele škol, 9(10), 27-29.

Svobodová, L. (2015). Proti skrytému záškoláctví nejsme bezbranní. Školní poradenství v praxi, 2(5), 12-14.

Švaříček, R., Šed’ová, K., Janík, T., Kaščák, O., Miková, M., Nedbálková, K., ... Zounek, J. (2007). Kvalitativní výzkum v pedagogických vědách. Praha: Portál.

Thornton, M., Darmody, M., \& McCoy, S. (2013). Persistent absenteeism among Irish primary school pupils. Educational Review, 65(4), 488-501.

Trhlíková, J. (2012). Předčasné odchody ze vzdělávání na středních školách. Kvalitativní analýza rozhovorů s experty a príklady dobrých praxí. Praha: NúV. Dostupné z http://www .nuv.cz/uploads/Vzdelavani_a_TP/Predc_odch_rozh_dobre_praxe_pro_www.pdf

Wang, M.-T., Kiuru, N., Degol, J. L., \& Salmela-Aro, K. (2018). Friends, academic achievement, and school engagement during adolescence: A social network approach to peer influence and selection effects. Learning and Instruction, 58, 148-160.

Mgr. Klára Šlapalová Ústav pedagogických věd

Filozofická fakulta, Masarykova univerzita Arna Nováka 1, 60200 Brno slapalova@mail.muni.cz

doc. PhDr. Petr Hlad'o, Ph.D. Ústav pedagogických věd Filozofická fakulta, Masarykova univerzita Arna Nováka 1, 60200 Brno hlado@phil.muni.cz 